\title{
Health Status of the Nase (Chondrostoma nasus) in Breeding Farms from the Jihlava River Basin
}

\author{
Lukáš Reček $^{1}$, Miroslava Palíková ${ }^{1}$, Antonín Lojek $^{2}$, Stanislav Navrátil $^{1}$ \\ ${ }^{1}$ Department of Veterinary Ecology and Environmental Protection, Faculty of Veterinary Hygiene and Ecology \\ University of Veterinary and Pharmaceutical Sciences Brno, Czech Republic \\ ${ }^{2}$ Department of Free Radical Pathophysiology, Institute of Biophysics AS CR, v.v.i., Brno, Czech Republic
}

Received November 20, 2007

Accepted June 11, 2008

\begin{abstract}
This study compares two fish farms in the Jihlava River basin that differ mainly in the intensity of rearing of the nase fry and in water sources. During rearing, we observed the health condition of fry from hatching to expedition at the age of one year. Four species of parasites (i.e., Ambiphrya ameiuri, Apiosoma piscicolum, Trichodina sp., Diplostomum spathaceum) were found to infest the fish and Aeromonas hydrophila was isolated by bacterial culture. In both breeding facilities the intensity and prevalence of Ambiphrya ameiuri increased during the summer. The state of health and its development including the recognised infections was similar in both farms. Immunological indicators such as differential white cell count, absolute white cell count and the oxidative burst in autumn were evaluated in the fry samples. Although fry from both farms had similar health condition, the results on immunological indicators show that fry from farm I are more exposed to the effects of stressors. In the next phase, we confronted immunological indicators of fry from farm II and brood fish from the Jihlava River. The results show differences in immunological indicators, which could be caused by a variety of stress factors having different effects on the immune system of these two fish categories. The environment affects greatly the immunity of juvenile as well as brood fish. It reflects in the different levels of immunological indicators in the comparison of fry from two farms as well as in the comparison of fry and brood fish from the river.
\end{abstract}

Chemiluminescence, phagocytic activity, brood fish, fingerling

The nase (Chondrostoma nasus) belongs to reophilic fish species, whose population in the wild water was reduced in the last few decades because of the dam building, flow fragmentation, loss of suitable gravel substratum, organic strain etc. This population has been extinct or badly devastated in many places (Lusk 1995; Lusk et al. 1998). For that reason the nase is classified as an endangered species in the Czech Republic (Lusk et al. 2004). This is why it is necessary to release artificially reared fry. Fry are reared under various conditions of intensification. The important condition that affects or restricts the artificial spawning and breeding utilisation of reophilic fish species, is the health condition of the individual age categories. It depends on the used technology of spawning and hatching, on the quality and substantiality of accessible water sources and on the presence of disease agents as well. Very important factor is the quality and resistance of brood fish to most serious diseases (Lucký and Navrátil 1986). A great advantage of artificial spawning, when observing all technology rules, is the prevention of infectious agent transmission. However, transmission of viral infection agents may present some danger (Lucký 1986; Lucký and Navrátil 1986). The health condition of the hatched fry is influenced mainly by the water and feed quality (Lucký and Navrátil 1986). In the case of the youngest fry categories, great dangers are posed by protozoan ectoparasitoses because of the fast spread with the possibility of the higher or total death loss caused by high fish concentration (Kouřil et al. 1984; Navrátil 1991).

Address for correspondence:

Lukáš Reček

Department of Veterinary Ecology and Environmental Protection

Faculty of Veterinary Hygiene and Ecology

University of Veterinary and Pharmaceutical Sciences Brno

Palackého 1-3, 61242 Brno

Czech Republic

Phone: +420774733644

E-mail: lukas.recek@centrum.cz

http://www.vfu.cz/acta-vet/actavet.htm 
Different influences of the environment and the way of rearing may cause stressful situations in breeding fish, which may lead to a decrease in the growth rate, food intake and reproduction. Among very important attributes of stress is its impact on both specific and non-specific parts of the immune system of the rearing fish. Stressed fish are more predisposed for disease. It is due to the interplay between the neuroendocrine system and the immune system in fish, which may lead to immune suppression under stress conditions (Espelid et al. 1996). The stress factors that influence the immune function in fish can be divided into two broad groups, namely those occurring naturally and those that are artificial. Natural stress factors include the season, temperature, salinity and photoperiod as well as social stress. In general, artificial stress factors are man-made, and involve pollutants, handling, sorting, transport etc. (Bly et al. 1997; Muiswinkel et al. 1999). Finally, the immune response of fish depends not only on these external factors but also on the internal ones, such as age and sexual cycle.

There are many possible ways to assess the influence of these factors on both parts of the fish immune system. One of these is the measuring the phagocytic activity as the main nonspecific mechanism, which plays a very important role particularly at lower temperatures when the production of specific antibody is reduced or disrupted (Bly and Clem 1992).

Many factors may suppress the phagocytic activity. If their action is summed up, they can reduce the phagocytic activity and act in favour of potentially pathogenic micro-organisms (Boleza et al. 2001).

Phagocytic cells are present in many fish tissues (Ainsworth 1992; Secombes and Fletcher 1992) and the rate of phagocytic activity differs by the type of tissue (Vazzana et al. 2003). The phagocytic activity is measured by several methods when assessment the quantity of ingested particles (Steinhagen and Jendrysek 1994), the reduction of tetrazolium salts (Secombes 1993) and measurement the intensity of chemiluminescence (Mathews et al. 1990) are used in fish today. Measurement of the phagocytic activity by zymozan-stimulated chemiluminescence in whole blood was chosen for experimental purposes (Kubala et al. 1996). The respiratory burst intensity is measured while the reactive oxygen species (ROS) are released that have bactericidal activity. It plays an important role in the process of non-specific defence system (Roberts 2001).

The objective of this work was to compare the health status of the nase during fry rearing in two farms from the Jihlava River basin and to find whether there is a difference in the selected immunological indicators of this fry at the end of their rearing, before they are planted to rivers. Another aim was to compare these immunological indicators with values of brood fish from the river as well as to study the influence of environmental conditions on clinically healthy fish.

\section{Materials and Methods}

The material for the study came from two localities of the Jihlava River basin. The first farm is situated closely the Jihlava River in its barbel zone at 93 river $\mathrm{km}$. The Jihlava River is the main source of water for the farm. The farm takes up an area of 3.8 ha. There is an administrative building, hatchery and ditch system and some greater ponds. Brood fish of the nase came from the Jihlava River basin. An electric shocker was used for catching these fish. Farm II is situated higher up on the river at $120 \mathrm{r}$. km. It is composed of the hatchery and some small rectangular ponds for rearing fry and stocking older and brood fish for the transition period. A water source for ponds and the hatchery is from a flow pond above the farm. The flow pond is also used for rearing brood fish of the nase and there can be a health risk for hatching fry in the hatchery caused by the parasitic infection. There are other $0.5-1$ ha large rearing ponds outside the farm for rearing, too. Water for these ponds comes from a small clear rill from the Jihlava River basin. Brood fish of the nase for artificial spawning come mainly from the Jihlava River basin caught by the electric fish shocker and from the flow pond above the farm.

Farm I receives water directly from the Jihlava River. For this reason there is no deficiency of water but a vegetation cloud periodically occurs in the summer period. Another disadvantage may be the transfer of aetiological agents from wild fish population in the river to the rearing fish. Rearing ponds outside farm II have an inconstant water source in summer and an overgrowth of aquatic plants occurs at the same time. On the other hand, this water is clear of any parasites because there are no wild adult fish as a source of the infection. Rearing 
intensity is higher on farm I compared to farm II, with a density of nase fry on farm I of about 50 pcs per $\mathrm{m}^{3}$. To the contrary, farm II rears nase fry at a density of ca $10-15$ pcs per $\mathrm{m}^{3}$. Losses on farm I during rearing are higher (ca $50-60 \%$ ) than on farm II, where losses are about 30\%. Farm I uses daily the crush feeding mixture marked as KP, which is feeding mixture for carp, and they dung water to support the growth of natural feed. Farm II uses corn groats to feed fry thrice per week. Natural feed is important mainly at the beginning of rearing on this farm.

The investigated fish were nase fry from hatching to the age of a few months. During rearing no medication was applied in any form. A sample of about 6-16 pcs was taken each time. Fish were transported to the laboratory for examination in polyethylene sacks and examined in the native form. In order to obtain a complete determination of parasites, a certain number of wet mounts were made, fixed and stained. We carried out bacterial cultivation on blood agar and on a culture medium according to Anacker and Ordal (1959) in indicated cases. The youngest fish were examined by the compression method. In older stages, skin was examined by scraping one half of the body to the slide. Examination of the gills was done by the compression method with two gill arches. Examination of the eyes and viscera were done by the compression method, too. The prevalence of parasitic infection was expressed in per cent of invaded fish in individual samples. The intensity was expressed by the number of protozoa found in a microscopic field at a certain magnification or by an absolute number. In all, 117 specimens of the nase fry were examined for the presence of parasites.

Blood was collected from 26 pcs of fry at the end of the study period in the autumn. Moreover, further blood samples were collected from 13 pcs of brood fish and 13 pcs of overwintering fry from farm II during the spawning period in the spring. Blood was collected by cardiac puncture with the capillary tube (volume $60 \mu 1$ with $0.5 \mu 1$ heparin) in fry and by the syrette with $5 \mu$ l heparin when we took $0.5 \mathrm{ml}$ of blood from brood fish. Blood smears were stained by Pappenheim's method to determine the differential white blood cell count. Absolute white blood cell counts were determined by Bürker's cell (Svobodová et al. 1986). Phagocytic activity levels were measured by the zymozan-stimulated chemiluminescence (Kubala et al. 1996). The measured data included peak of CL $(\mathrm{mV})$ and the integral of CL $(\mathrm{mV} / \mathrm{s})$. The peak and the integral of CL were transferred to 1000 of phagocytes. The statistic evaluation of the data was carried out by the hypothesis test of two independent groups ( $t$-test). The statistic program STAT PLUS 1.01 was used for the evaluation (Matoušková et al. 1992).

\section{Results}

We found four parasite species by parasitological examination in fry of the nase: protozoans Ambiphrya ameiuri, Apiosoma piscicolum, Trichodina sp. and the metacercarial stage of the eye fluke (Diplostomum spathaceum), Table 1 and 2. The highest intensity and prevalence were found in protozoan Ambiphrya ameiuri on both farms in the summer period (Fig. 1 and 2). The intensity of infection did not cause any changes on the fry skin visible on gross inspection.

After microscopic detection of bacteria in the light microscope, we performed bacterial cultivation of the skin and found the bacterium Aeromonas hydrophila.

Table 1. Occurrence of parasites of fry on farm I

\begin{tabular}{|c|c|c|c|c|c|c|c|c|c|c|c|c|c|c|c|c|}
\hline & \multicolumn{2}{|c|}{17.5 . } & \multicolumn{2}{|c|}{15.6.} & \multicolumn{2}{|c|}{30.6 . } & \multicolumn{2}{|c|}{26.7.} & \multicolumn{2}{|c|}{12.8 . } & \multicolumn{2}{|c|}{26.8 . } & \multicolumn{2}{|c|}{14.9.} & \multicolumn{2}{|c|}{7.10 . } \\
\hline & I & $\mathrm{P}[\%]$ & I & $\mathrm{P}[\%]$ & I & $\mathrm{P}[\%]$ & I & $\mathrm{P}[\%]$ & I & $P[\%]$ & I & $\mathrm{P}[\%]$ & I & $\mathrm{P}[\%]$ & I & $\mathrm{P}[\%]$ \\
\hline Number of pcs & & 5 & & 9 & & 0 & & 8 & & 9 & & & 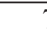 & & 7 & \\
\hline $\begin{array}{l}\text { Ambiphrya ameiuri } \\
\text { skin, pcs } / \times 100\end{array}$ & 0 & 0 & $4-50$ & 100 & 0 & 0 & $0-1$ & 12.5 & 0 & 0 & 0 & 0 & 0 & 0 & 0 & 0 \\
\hline $\begin{array}{l}\text { Trichodina } \text { sp. } \\
\text { skin, pcs } \times 100\end{array}$ & 0 & 0 & 0 & 0 & $0-1$ & 30 & $0-1$ & 50 & 0 & 0 & 0 & 0 & 0 & 0 & 0 & 0 \\
\hline
\end{tabular}

$\mathrm{I}=$ intensity, $\mathrm{P}=$ prevalence

Table 2. Occurrence of parasites of fry on farm II

\begin{tabular}{|l|c|c|c|c|c|c|c|c|c|}
\hline \multirow{2}{*}{} & \multicolumn{2}{|c|}{19.5.} & \multicolumn{2}{c|}{1.7.} & \multicolumn{2}{c|}{19.8.} & \multicolumn{2}{c|}{11.10.} \\
\cline { 2 - 10 } & \multicolumn{2}{|c|}{$\mathrm{I}$} & $\mathrm{P}[\%]$ & $\mathrm{I}$ & $\mathrm{P}[\%]$ & $\mathrm{I}$ & $\mathrm{P}[\%]$ & $\mathrm{I}$ & $\mathrm{P}[\%]$ \\
\hline Number of pcs & \multicolumn{2}{|c|}{16} & \multicolumn{2}{|c|}{10} & \multicolumn{2}{|c|}{8} & \multicolumn{2}{c|}{10} \\
\hline Ambiphrya ameiuri skin, pcs $\times 100$ & 0 & 0 & $0-30$ & 100 & 0 & 0 & 0 & 0 \\
\hline Apiosoma piscicolum skin, pcs/ $\times 100$ & 0 & 0 & $0-1$ & 10 & 0 & 0 & 0 & 0 \\
\hline Diplosthomum spathaceum eye, abs value & 0 & 0 & 0 & 0 & 0 & 0 & 2 & 20 \\
\hline
\end{tabular}

$\mathrm{I}=$ intensity, $\mathrm{P}=$ prevalence 


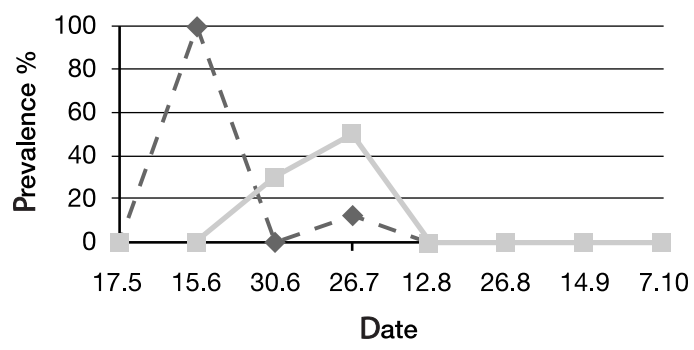

- - A. ameiuri $\longrightarrow$ Trichodina sp.

Fig. 1. The prevalence of parasites of fry in farm I

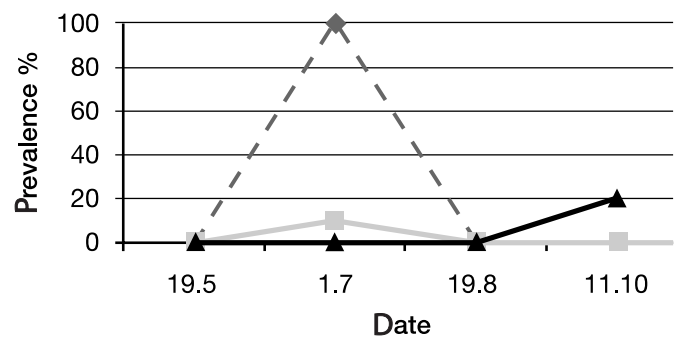

A. ameiuri

A. piscicolum

D. spathaceur

Fig. 2. The prevalence of parasites of fry in farm II

Table 3. Differential count value of fry in autumn

\begin{tabular}{|l|c|c|c|c|c|c|c|}
\hline Differential count \% & Lymphocytes & N-myelocytes & N-metamyelocytes & N-band & N-segments & Monocytes & Blast cells \\
\hline Farm I (fry) & $85.0 \pm 4.5$ & $7.8 \pm 3.0$ & $3.0 \pm 2.1$ & $2.9 \pm 1.7$ & $0.7 \pm 0.7$ & $0.6 \pm 0.4$ & 0 \\
\hline Farm II (fry) & $83.3 \pm 9.7$ & $10.3 \pm 6.2$ & $2.7 \pm 1.3$ & $2.1 \pm 2.0$ & $0.5 \pm 0.6$ & $1 \pm 1$ & 0 \\
\hline
\end{tabular}

Table 4. The phagocyte activity value of fry in autumn

\begin{tabular}{|l|c|c|}
\hline Value & Farm n. I (fry) & Farm n. II (fry) \\
\hline Number of specimens & 13 & 13 \\
\hline$\sum$ leukocytes $\left(\mathrm{G} \cdot 1^{-1}\right)$ & $68.3 \pm 25.1^{* *}$ & $35.7 \pm 11.3^{* *}$ \\
\hline$\sum$ phagocytes $\left(\mathrm{G} \cdot 1^{-1}\right)$ & $10.1 \pm 4.4^{*}$ & $6.0 \pm 4.3^{*}$ \\
\hline Peak $/ 1000$ & $0.6 \pm 0.3^{* *}$ & $2.7 \pm 1.6^{* *}$ \\
\hline Integral/1000 & $1186.9 \pm 571.6^{* *}$ & $4717.4 \pm 2762.4^{* *}$ \\
\hline$*=(p<0.05), * *=(p<0.01)$
\end{tabular}
the other hand, we found a higher rate of phagocytic activity $(p<0.01)$ in fish from farm II (Table 4).

There was no difference between the level of phagocytic activity in the autumn and the spring in nase fry from farm II but there was a difference in the absolute phagocyte cell count of which the fish in the spring had a low rate $(p<0.05)$. On the other hand, the brood fish had a markedly higher level of chemiluminescence $(p<0.01)$ (Table 6 ) and the differential white cell count had a high number of neutrophil granulocytes $(p<0.01)$ (Table 5). 
Table 5. The differential leukocyte count of fry and brood fish in spring

\begin{tabular}{|l|c|c|c|c|c|c|c|}
\hline Differential count \% & Lymphocytes & N-myelocytes & N-metamyelocytes & N-band & N-segments & Monocytes & Blast cells \\
\hline Farm II (brood fish) & $46 \pm 16$ & $25.4 \pm 10.8$ & $13.9 \pm 6.1$ & $5.2 \pm 2.6$ & $5.3 \pm 4.2$ & $3.4 \pm 1.3$ & $0.8 \pm 0.7$ \\
\hline Farm II (fry) & $90.7 \pm 3.6$ & $5.2 \pm 1.4$ & $1.6 \pm 1.3$ & $1.1 \pm 1$ & $0.7 \pm 0.7$ & $0.7 \pm 0.6$ & $0.04 \pm 0.1$ \\
\hline
\end{tabular}

Table 6 . The phagocyte activity of fry and brood fish in spring

\begin{tabular}{|l|c|c|}
\hline Value & Farm n. II (brood fish) & Farm n. II (fry) \\
\hline Number of specimens & 13 & 13 \\
\hline$\sum$ leukocytes $\left(\mathrm{G} \cdot 1^{-1}\right)$ & $27.5 \pm 10.5$ & $31.8 \pm 9.1$ \\
\hline$\sum$ phagocytes $\left(\mathrm{G} \cdot 1^{-1}\right)$ & $15.3 \pm 8.5^{* *}$ & $2.8 \pm 1^{* *}$ \\
\hline Peak $/ 1000$ & $13.6 \pm 6.9^{* *}$ & $2.8 \pm 1.7^{* *}$ \\
\hline Integral/1000 & $18169.2 \pm 11806.1^{* *}$ & $5384 \pm 2938.6^{* *}$ \\
\hline$*(p<0.05), * *=(p<0.01)$
\end{tabular}

problem with the decay of higher plants at the same time.

The amount of parasites began to decrease when the vegetation cloud disappeared and the higher plants were removed. Ambiphrya ameiuri was found as the main species of parasite. This parasite itself does not present a high health risk for fry in good health condition. Its way of fixation does not cause any damage of the gill epithelium or epidermal cells. Its pathological action is associated with cellular irritation by overpopulated parasite (Lom and Dyková 1992) and by the aggravation of the health status of fry which was weak or ill before the invasion of the parasite. We found that the infection does not cause any clinical changes on the skin.

The finding of the bacteria Aeromonas hydrophila on the culture medium was not of great importance. We did not find any pathological process on the skin of the examined fish. Aeromonas hydrophila can be found on the skin of fish in good health condition; its pathological actuating is caused by impaired health, damage and deterioration of quality of the environment (Roberts 2001).

As we found in the autumn blood samples, there was no significant difference in the differential white cell count between fish from both farms. Fish from farm I had a higher rate of the absolute white cell count $(p<0.01)$ and a higher rate of the total phagocyte cell count $(p<0.05)$ compared to fish from farm II. On the other hand, fish from farm II had a higher level of the phagocytic activity $(p<0.01)$. It could be caused by higher stress pressure in fish from farm I that influences the chemiluminescence level.

The main difference seems to be in the quality of the water source for rearing ponds and for containing the fry before expedition. Water from the middle course of the Jihlava River is under a deeper anthropogenic impact than water from the course of small rills. The anthropogenic impact, such as pollution, could cause a lower rate of oxidative burst (Warinner et al. 1988; Dunier and Siwicki 1993). Polluted water affects the phagocytic activity not only by the immunosuppressive substance content but also by a decreasing level of dissolved oxygen. The low level of dissolved oxygen is another important stress factor (Boleza et al. 2001; Valenzuela et al. 2005). The other potential factor that may have an effect on the oxidative burst level is the availability and quality of feeding, especially the positive influence of vitamin C and E and polyunsaturated fatty acids (Secombes 1994).

A fish population is not under the influence of one stressor only under natural conditions or the rearing conditions that may differ in intensity. There is a combination of many influences that act together or gradually, such as the technological process on the breeding farm. Of the many different stressors, the level of dissolved oxygen in water has a very important influence of the oxidative burst rate (Ortuño et al. 2002). 
In the second phase of our experiment, we compared the differential white cell count and the rate of oxidative burst in overwintering fry from farm II and brood fish from the Jihlava River. There was no difference between the level of phagocytic activity in the autumn and the spring in the nase fry from farm II but there was a difference in the total phagocyte cell count because the fish in the spring had a low rate. It could be due to the physical condition after winter or seasonal changes which are reported in fish; however, these studies focused on adult fish capable of spawning (Collazos et al. 1995; Kortet et al. 2003).

On the contrary, the brood fish had a markedly higher rate of the chemiluminescence and the differential white cell count had a high number of neutrophil granulocytes. Both categories, overwintering fry and brood fish from the Jihlava River are under stress condition. Nevertheless, the stress condition in these two fish groups was not caused by the same situations. The fry was caught with the net, transported from the pond and gathered at a high density in a tank before being planted into the river. The high density of fish in the tank could change the ratio of dissolved gases in water, which has a very important influence on the oxidative burst and could cause the difference in the oxidative burst between fry and brood fish (Boleza et al. 2001; Ortuño et al. 2002). To the contrary, the brood fish were stressed by being caught with an electric fishing gear. Transport and handling are other important stressful situations. One very important factor that may have participated in the different values between the fry and the brood fish, is the fact that the brood fish was in the spawning period at this time. Immunological performance may be subject to rapid temporal changes at this time due to possible resource re-allocation between the immune system and the reproduction, or through immunomodulation by reproductive hormones. Some parts of the immune system may be suppressed during spawning, others may remain unaffected (Kortet et al. 2003).

The most serious health problem in the summer time in observed farms was the occurrence of conditional parasites. These parasites appear when fish has a poor health condition, they are stressed or when the quality of the environment is impaired, which corresponds with the deterioration environment in the watched period, see above. Parasitic infection is impossible to be affected by the application of any efficacious remedy at this time. It's possible only after catching fish with net in the spring and the autumn period. However, there is a minimal occurrence of the parasitic infection. A bath is only preventive and it can cause an unnecessary stress to fish. The optimization of the environmental conditions and take advantage of fish ability to cope with unfavourable conditions is the main tool for the prevention. Generally fry from farm I seems to be under mor severe stress because of rearing intensity and worse environment. The Jihlava River is marked in water quality as a class IV, highly polluted water (www.env.cz). Conditions for rearing fry of the nase are worse at the farm I. Reduction of the intensity, increase of the water flow and decrease side dress by the dung could lead to decreased losses and improved environment for fry of the nase at this farm.

Artificial spawning and rearing are powerful tools to refill and rescue the endangered wild population of the nase, but there are many problems to solve. Optimized environmental conditions could reduce loss during the rearing that also improve the production of quality fry, which has better chance in the natural environment. However, at this time problems with the intraspecific diversity reduction appear (Lusk et al. 2004). It is a great risk for native fish species because of natural waters management in the Czech Republic.

\section{Zdravotní stav ostroretky stěhovavé (Chondrostoma nasus) na chovných farmách v povodí řeky Jihlavy}

Tato práce srovnává dva chovy ostroretky stěhovavé v povodí řeky Jihlavy. Ty se od sebe liší především intenzitou odchovu plůdku a vodním zdrojem pro oba chovy. Během od- 
chovu jsme sledovali zdravotní stav plůdku od vykulení po expedici v jednom roce věku. Byly zachyceny 4 druhy parazitů (Ambiphrya ameiuri, Apiosoma piscicolum, Trichodina sp., Diplostomum spathaceum). Bakteriologickou kultivací byla zachycena Aeromonas hydrophila. Výraznější nárůst intenzity a prevalence byl zaznamenán v letním období u Ambiphrya ameiuri v obou sledovaných chovech. Vývoj zdravotního stavu a zjištěná infekce měla v obou případech podobný průběh. Plůdek ostroretky pak byl na podzim porovnán na základě imunologických parametrů jako diferenciální počet leukocytů, absolutní počet leukocytů a hodnota oxidativního vzplanutí. Ačkoli měl plůdek z obou farem podobnou zdravotní kondici, tak výsledky imunologických hodnot ukazují, že ryby z první sledované farmy jsou pod větším stresovým tlakem. V další fázi jsme porovnávali imunologické parametry u přezimovaného plůdku z farmy II a generačních ryb původem z řeky Jihlavy. Výsledek prokázal rozdílné imunologické hodnoty u porovnávaných skupin ryb. Tento rozdíl by mohl být způsoben odlišnými stresovými faktory, jež nemají stejný efekt na imunitní systém těchto rybích kategorií. Okolní prostředí má na imunitu plůdku i generačních ryb významný vliv. Odráží se v odlišných hodnotách imunologických parametrů jak v rámci porovnání plůdku ze dvou odchovných zařízení tak i při porovnání plůdku a generačních ryb, které jsou získávány z říčního prostředí.

\section{Acknowledgement}

The research was supported by the Ministry of Agriculture, NAZV QF3028.

\section{References}

Ainsworth AJ 1992: Fish granulocytes: morphology, distribution and function. Annu Rev Fish Dis 2: 123-148

Anacker RL, Ordal EJ 1959: Studies on the myxobacterium Chondrococcus columnaris. 1. Serological typing. J Bacteriol 78: 25-32

Bly JE, Clem LW 1992: Temperature and teleost immune function. Fish Shellfish Immunol 2: 159-171

Bly JE, Quiniou SM, Clem LW 1997: Environmental effects on fish immune mechanisms. Dev Biol Stand 90: $33-43$

Boleza KA, Burnett LE, Burnett KG 2001: Hypercapnic hypoxia compromises bactericidal activity of fish anterior kidney cells against opportunistic environmental pathogens. Fish Shellfish Immunol 11: 593-610

Collazos ME, Barriga C, Ortega E 1995: Seasonal variations in the immune system of the cyprinid Tinca tinca. Phagocytic function. Comp Immunol Microbiol Infect Dis 18: 105-113

Dunier M, Siwicki AK 1993: Effects of pesticides and other organic pollutants in the aquatic environment on immunity of fish: a review. Fish Shellfish Immunol 3: 423-438

Espelid S, Lokken GB, Steiro K, Bogwald J 1996: Effects of cortisol and stress on the immune system in Atlantic salmon (Salmo salar L.). Fish Shellfish Immunol 6: 95-110

Kouřil J, Svobodová Z, Vykusová Z, Hamáčková J 1984: Antiparasite and antifungus bath of fry of common carp, herbivorous fish and catfish. Reseach Institute of Fish Culture and Hydrobiology, Vodňany. Methods 15: 8 p.(In Czech).

Kortet R, Taskinen J, Sinisalo T, Jokinen I 2003: Breeding-related seasonal changes in immunocompetence, health state and condition of the cyprinid fish, Rutilus rutilus. Biol J Linnean Soc 78: 117-127

Kubala L, Lojek A, Číž M, Vondráček J, Dušková M, Slavíková H 1996: Determination of phagocyte activity in whole blood of carp (Cyprinus carpio) by luminol-enhanced chemiluminiscence. Vet Med-Czech 41: 323-327

Lom J, Dyková I 1992: Protozoan parasites of fishes. Developments in aquaculture and fisheries science, Vol. 26. Elsevier, Amsterdam, 315 p.

Lucký Z 1986: Health care and fish diseases prevention (prevention of the fish diseases). Naše vojsko, Prague, 201 p. (In Czech).

Lucký Z, Navrátil S 1986: Veterinary guides in artificial reproduction of fish. Book of papers. Vodňany, Slovakian Zoological Association, pp. 204-210 (In Czech).

Lusk S 1995: The status of Chondrostoma nasus in waters of the Czech Republic. Folia Zool 44: 1-8

Lusk S, L Lusková V, Halačka K, Šlechta V, Šlechtová V 1998: Trends and production of a fish communities of the barbel zone in a stream of the Czech Republic. Folia Zool 47 (Suppl.): 67-72

Lusk S, Hanel L, Lusková V 2004: Red List of the ichthyofauna of the Czech Republic: Development and present status. Folia Zool 53: 215-226

Mathews ES, Warinner JE, Weeks BA 1990. Assays of immune function in fish macrophages. Techniques used as indicators of environmental stress. In: Stolen JS, Fletcher DP, Anderson BS, Robertson BS (Eds.). Tech Fish Immunol 1. Fair Haven, NJ, USA: SOS Publication, p.155-163. 
Matoušková O, Chalupa J, Cígler M, Hruška K 1992: STAT-Plus-Manual, version 1.01 (In Czech). Veterinary Reseach Institute, Brno, 168 p.

Ministry of the Environment of the Czech Republic 2005: www.env.cz (visited 12. 4. 2008).

Muiswinkel Van WB, Wiegertjes GF, Stet RJM 1999: The influence of environmental and genetic factors on the disease resistance of fish. Aquaculture 172: 103-110

Navrátil S 1991: Parasitoses in the fry of selected freshwater fish species under the conditions of stripping and rearing. Acta Vet Brno 60: 357-366

Ortuño J, Esteban MA, Meseguer J 2002: Lack of effect of combining different stressors on innate immune responses of seabream (Sparus aurata L.). Vet Immunol Immunopathol 84: 17-27

Roberts RJ 2001: Fish pathology. 3rd ed. W.B. Saunders, Edinburgh, 472 p.

Secombes CJ, Fletcher TC 1992: The role of phagocytes in the protective mechanisms of fish. Annu Rev Fish Dis 2: $53-71$

Secombes CJ 1993: Isolation of salmonid macrophages and analysis of their killing activity. Tech Fish Immunol 1. SOS Publications,USA, pp. 134-154.

Secombes CJ 1994: Enhancement of fish phagocyte activity. Fish Shellfish Immunol 4: 421-436

Steinhagen D, Jendrysek S 1994: Phagocytosis by carp granulocytes; in vivo and in vitro observations. Fish Shellfish Immunol 4: 521-525

Svobodová Z, Pravda D, Paláčková J 1986: Unified methods of fish haematological investigation. Research Institute of Fish Culture and Hydrobiology, Vodňany. Methods 22: 32 p. (In Czech).

Valenzuela A, Silva V, Tarifeno E, Klempau A 2005: Effect of acute hypoxia in trout (Oncorhynchus mykiss) on immature erythrocyte release and production of oxidative radicals. Fish Physiol Biochem 31: 65-72

Vazzana M, Parrinello D, Cammarata M 2003: Chemiluminiscence response of beta-glucan stimulated leukocytes isolated from different tissue and peritoneal cavity of Dicentrarchus labrax. Fish Shellfish Immunol 14: 423-434

Warinner JE, Mathews ES, Weeks BA 1988: Preliminary investigations of the chemiluminescent response in normal and pollutant-exposed fish. Mar Environ Res 24: 281-284 